\title{
Intracellular Chloride Concentration and Evidence for the Existence of a Chloride Pump in Frog Skeletal muscle
}

\author{
Tetsuji HironaKa and Shoji Morimoto \\ Department of Pharmacology, Teikyo University \\ School of Medicine, Tokyo 173, Japan
}

\begin{abstract}
Intracellular chloride concentration in frog sartorius muscle was determined at $20^{\circ} \mathrm{C}$ utilizing ionic permeability change of the membrane for an ion-selective electrode. The membrane potential and external potassium concentration relation was obtained with changes in $\mathrm{pH}$. Using the constant field equation with a condition given by the crossing point in the two relations obtained with the two different $\mathrm{pH}$, the intracellular chloride concentration was estimated to be $3.7 \pm 0.18 \mathrm{~mm}$ (mean \pm S.E.M.) with a 0.76 of the activity coefficient for chloride in Ringer's solution. The chloride potential $(-88.5 \pm 1.26 \mathrm{mV})$ was significantly positive to the resting potential $(-94.8 \pm 1.09 \mathrm{mV})$, suggesting that a chloride pump may be working in the frog skeletal muscle. The existence of the chloride pump was supported further by the fact that the depolarization induced by the $\mathrm{pH}$ increase became smaller with cooling and finally disappeared when cooled below $5^{\circ} \mathrm{C}$.
\end{abstract}

In frog sartorius muscle, the chloride conductance of the membrane is about twice as large as the potassium conductance, and the distribution of chloride may be determined by a purely passive mechanism (HodGKIN and HorowICZ, 1959; HutTer and Noble, 1960; Adrian, 1960, 1961). On the other hand, an active movement of chloride was suggested from the fact that the membrane potential varied with the $\mathrm{pH}$ in a medium which specifically alters the chloride conductance (HUTTER and WARNeR, 1967), although LiNG and GERARD (1949) found no clear variation of the resting potential with changes in $\mathrm{pH}$.

Recently direct measurements of chloride activity in frog sartorius muscle using ion-selective electrodes have also shown that the intracellular chloride concentration appears to be higher than the value predicted on the basis of a passive distribution of chloride (KERNAN et al., 1974; BOLTON and VAUGHAN-JONES, 1977). The major uncertainties in these measurements are the liquid junction potentials between the $\mathrm{KCl}$ salt bridges and the myoplasm (COLE and MoORE, 1960; HiroNAKA and MoRImoto, 1979), and the possible contribution of interfering anions to the electrode potentials (WALKER and BROWN, 1977). Inserting the large elec-

Received for Publication October 15, 1979

弘中哲治，森本昇司 
trode into the cell also might cause sufficient damage to allow leakage. As the difference between the chloride equilibrium potential and the resting membrane potential was generally small, it might reasonably be ascribed to some experimental error (BOLTON and VAUGHAN-JONES, 1977).

The present study describes an entirely different kind of determination of intracellular chloride concentration and offers evidence for the existence of a chloride pump in frog sartorius muscle with special reference to accurate potential measurements (HironAKA and MorimoTo, 1979).

\section{METHODS}

Theoretical. If $\mathrm{pH}$ specifically alters the chloride permeability of the membrane (HUTTER and WARNER, 1967), the ratio of change in the membrane potential to change in its permeability in the constant field equation (GoldmaN, 1943; HodGKIN and KATZ, 1949), Eq. 1, is given as a derivative of the membrane potential $(\mathrm{mV})$ with respect to chloride permeability, Eq. 2:

$$
\begin{gathered}
V_{\mathrm{m}}=\frac{R T}{F} \ln \frac{P_{\mathrm{K}}[\mathrm{K}]_{\mathrm{o}}+P_{\mathrm{Na}}[\mathrm{Na}]_{\mathrm{o}}+P_{\mathrm{Cl}}[\mathrm{Cl}]_{\mathrm{i}}}{P_{\mathrm{K}}[\mathrm{K}]_{\mathrm{i}}+P_{\mathrm{Na}}[\mathrm{Na}]_{\mathrm{i}}+P_{\mathrm{Cl}}[\mathrm{Cl}]_{\mathrm{o}}} \\
\frac{R T}{F}\left(\frac{[\mathrm{Cl}]_{\mathrm{i}}}{P_{\mathrm{K}}[\mathrm{K}]_{\mathrm{o}}+P_{\mathrm{Na}}[\mathrm{Na}]_{\mathrm{o}}+P_{\mathrm{Cl}}[\mathrm{Cl}]_{\mathrm{i}}}-\frac{[\mathrm{Cl}]_{\mathrm{o}}}{P_{\mathrm{K}}[\mathrm{K}]_{\mathrm{i}}+P_{\mathrm{Na}}[\mathrm{Na}]_{\mathrm{i}}+P_{\mathrm{Cl}}[\mathrm{Cl}]_{\mathrm{o}}}\right)
\end{gathered}
$$

where $P$ refers to the ion permeability in the subscript, [ ] to the ion activity outside (o) or inside (i) the muscle fiber, and $R, T$ and $F$ have the conventional meanings.

From the condition of $d V_{\mathrm{m}} / d P_{\mathrm{C} 1}=0$, the following equation is derived to calculate the intracellular chloride activity:

$$
[\mathrm{Cl}]_{\mathrm{i}}=[\mathrm{Cl}]_{\mathrm{o}} \exp \left(V_{\mathrm{m}} F / R T\right)
$$

Material. Sartorius muscles of Rana nigromaculata were carefully removed to avoid damaging the pelvic end of the muscle, and they were dissected into small parts to ensure rapid perfusion around the muscle fibers within several seconds ( $c f$. HodGKIN and Horowicz, 1959). The muscle was mounted on a block in a chamber with a capacity of $0.6 \mathrm{ml}$. The block had a drain in the middle through which the muscle fibers were continuously perfused crosswise with solutions at a rate of $4 \mathrm{ml} / \mathrm{min}$. The experiments were carried out on the muscles in $1 \mathrm{hr}$ after the dissection at $20^{\circ} \mathrm{C}$.

Measurement of the membrane potential. Micro-electrodes with resistances between 5 and $10 \mathrm{M} \Omega$ and with tip potentials less than $1 \mathrm{mV}$ when filled with $3 \mathrm{M} \mathrm{KCl}$ were used for potential recordings. A coarse micro-electrode filled with $3 \mathrm{M} \mathrm{KCl}$ was used as a reference electrode. A special precaution was taken to eliminate "tip potentials" in the potential measurements ( $c f$. HironAKA and Morimoto, 1979). No appreciable change in potential was observed in the electrodes when the $\mathrm{pH}$ of the solution was altered. 
Solutions. Normal Ringer's solution was composed of (mM): $\mathrm{NaCl}, 115$, $\mathrm{KCl}, 2.5, \mathrm{CaCl}_{2}, 1.8$, tris maleate, 2.0, acetylglycine, 2.0, and was titrated with $\mathrm{NaOH}$ for the necessary pH (HutTER and WARNER, 1967). To alter potassium concentration in the solution; $\mathrm{Na}$ was substituted for $\mathrm{K}$. In the cooling experiments, a high Ca Ringer's solution ( $4 \mathrm{~mm}$ ) was used for stability of the muscle membrane in terms of the potential measurements.

\section{RESULTS}

Relation between membrane potential and external potassium concentration at different $p H$ values

The potential measurements were made on 5 fibers of a muscle 2-3 min after changing into the solution containing each $\mathrm{K}$ concentration for $\mathrm{pH} 7.2$, and a quick measurement was done on the 5 fibers for $\mathrm{pH} 8.2$ between 1 and 2 min after changing into the solution because of the transient effect of the $\mathrm{pH}$ increase (HuTTER and WARNER, 1967). After washing (30 min), the experiments were repeated for another $\mathrm{K}$ concentration.

The resting membrane depolarized with an increase in external $\mathrm{K}$ concentration as shown in Fig. 1 (filled circles). When the $\mathrm{pH}$ in each solution was raised, the membrane potential depolarized in the Ringer's solution containing $2.5 \mathrm{~mm}$ $\mathrm{K}$, but it hyperpolarized in a higher $\mathrm{K}$ concentration in Fig. 1 (filled squares).

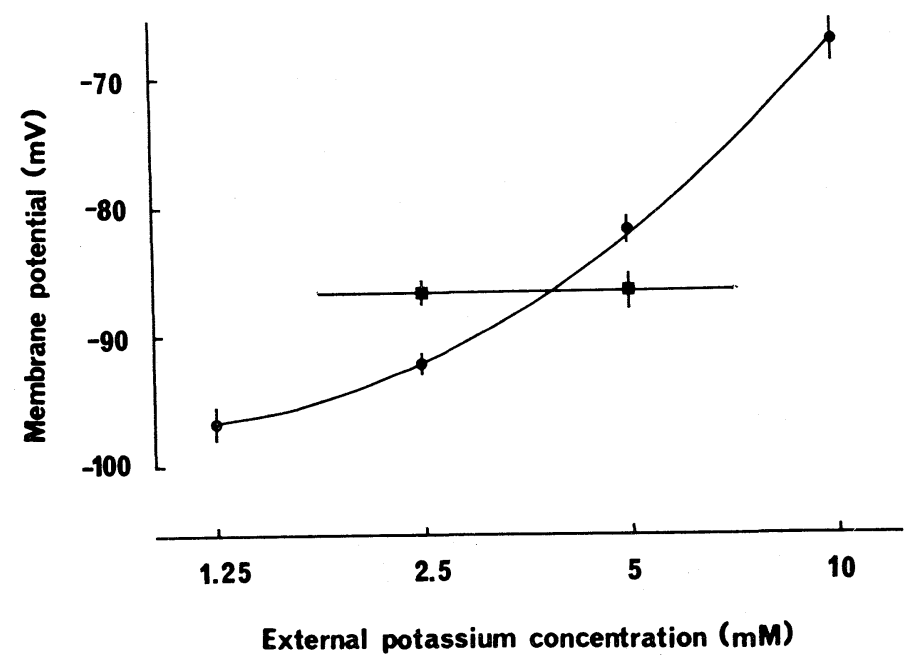

Fig. 1. Membrane potential-external potassium concentration relation in neutral and high $\mathrm{pH}$ Ringer's solutions at $20^{\circ} \mathrm{C}$. Ordinate: membrane potential in $\mathrm{mV}$. Abscissa: external potassium concentration in mM. Filled circles, $\mathrm{pH} 7.2$; filled squares, $\mathrm{pH}$ 8.2. The curve was drawn by a polynomial curve fitting. $-86.7 \mathrm{mV}$ and $3.85 \mathrm{~mm}$ at the cross. When the membrane potentials at 2.5 and $5 \mathrm{~mm}$ of external potassium with $\mathrm{pH}$ 8.2 were not close, two points were further added to fit a polynomial curve.

Vol. 30, No. 3, 1980 


\section{Calculation of intracellular chloride concentration}

At the crossing point in Fig. 1, the condition of $d V_{\mathrm{m}} / d P_{\mathrm{Cl}}=0$ derived in the theoretical section is fulfilled. A derived equation Eq. (3) was used to calculate the intracellular chloride concentration. The membrane potential obtained in Fig. 1 was corrected for the liquid junction potentials between Ringer's solution and $3 \mathrm{M} \mathrm{KCl}$, and the myoplasm and $3 \mathrm{M} \mathrm{KCl}$ solution by $-2.6 \mathrm{mV}$ (HrronaKA and Morimoto, 1979), and incorporated into Eq. (3). The results of 5 experiments are summarized in Table 1.

This equation can be rewritten to give:

$$
V_{\mathrm{m}}=\frac{R T}{F} \ln \frac{[\mathrm{Cl}]_{\mathrm{i}}}{[\mathrm{Cl}]_{\mathrm{o}}}
$$

where $V_{\mathrm{m}}$ represents the chloride equilibrium potential $\left(E_{\mathrm{C} 1}\right)$. The $E_{\mathrm{C} 1}$ was $-88.5 \mathrm{mV}$ on the average, which was clearly positive to the resting membrane potential by $6.3 \mathrm{mV}$ (Table 1). The clear difference in the potentials between the $E_{\mathrm{C} 1}$ and the $E_{\mathrm{m}}$ in Table 1 strongly suggests that a chloride pump may exist in the frog skeletal muscle.

Further evidence for the existence of a chloride pump

The membrane depolarization with $\mathrm{pH}$ increase was measured over a wide range of temperature $\left(2.5\right.$ to $\left.22^{\circ} \mathrm{C}\right)$ in Fig. 2. The membrane potential was firstly measured on 5 fibers of a muscle in the high Ca-Ringer's solution with pH 7.2, and secondly the potential change induced by the $\mathrm{pH}$ increase $(\mathrm{pH} 9.2)$ was measured on the 5 fibers as in Fig. 1 at a temperature. The muscle was then cooled down to a relevant temperature by circulating water with the temperature around the chamber for $30 \mathrm{~min}$, and the potential change induced by the $\mathrm{pH}$ increase was measured as above.

With cooling, the depolarization induced by the $\mathrm{pH}$ increase became smaller and finally disappeared when cooled below $5^{\circ} \mathrm{C}$ (Fig. 2), indicating that the chloride pump had been inhibited to attain a passive distribution of the chloride across the membrane. A slight depolarization observed with cooling was that

Table 1. Intracellular chloride concentration $[\mathrm{Cl}]_{\mathrm{i}}$, chloride potential $E_{\mathrm{C} 1}$, and resting membrane potential $E_{\mathrm{m}}$.

\begin{tabular}{cccc}
\hline Muscle & $\begin{array}{c}{\left[\mathrm{Cl}_{\mathrm{i}}\right.} \\
(\mathrm{mM})\end{array}$ & $\begin{array}{c}E_{\mathrm{Cl}} \\
(\mathrm{mV})\end{array}$ & $\begin{array}{c}E_{\mathrm{m}} \\
(\mathrm{mV})\end{array}$ \\
\hline 1 & 3.3 & -91.4 & -96.6 \\
2 & 3.4 & -90.6 & -96.4 \\
3 & 4.2 & -85.0 & -95.4 \\
4 & 4.0 & -86.0 & -90.6 \\
5 & 3.5 & -89.3 & -94.8 \\
\hline Mean \pm S.E. & $3.7 \pm 0.18$ & $-88.5 \pm 1.26$ & $-94.8 \pm 1.09$
\end{tabular}

In calculation the membrane potential as obtained in Fig. 1 was corrected for the liquid junction potentials. See text for the details. 


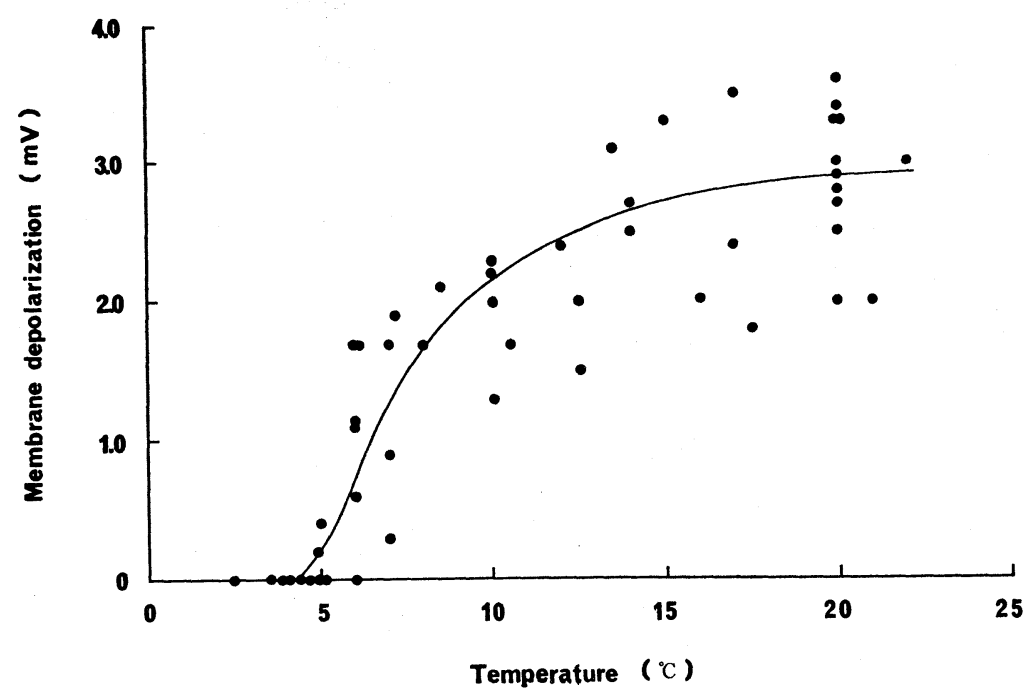

Fig. 2. Effect of temperature on the depolarization induced by the $\mathrm{pH}$ increase (7.2 to 9.2). Ordinate: change in membrane potential in $\mathrm{mV}$. Abscissa: temperature in ${ }^{\circ} \mathrm{C}$.

predicted on the physical basis from the amount of the cooling temperature. The potential was restored to the original level by rewarming the muscle fibers, but the depolarization effect by the $\mathrm{pH}$ increase was not recovered in 30 min after rewarming when the muscle was drastically cooled down, say below $5^{\circ} \mathrm{C}$.

\section{DISCUSSION}

In the present study, a specific permeability change of the membrane induced by a $\mathrm{pH}$ change was utilized for ion-selective electrode so that only a microelectrode filled with $3 \mathrm{M} \mathrm{KCl}$ needed to be introduced to measure the membrane potential, thereby keeping the intracellular ionic perturbation relatively small. Since the potential measurements were performed with special reference to accurate potential measurements without introducing the "tip potentials" (HIRONAKA and Mовімото, 1979), the error involved in Table 1 would be less than $4 \%$ in terms of the potential measurements $(1 \mathrm{mV}$ at most in Eq. 3).

When the experiment as in Fig. 1 and Table 1 was performed with a higher $\mathrm{pH}$ of 9.2, essentially the same result was obtained, e.g., the average $[\mathrm{Cl}]_{\mathrm{i}}, E_{\mathrm{Cl}}$ and $E_{\mathrm{m}}$ were $3.8 \mathrm{mM},-87.2 \mathrm{mV}$ and $-94.1 \mathrm{mV}$ respectively $(n=3)$. However, the reversibility of the measurements was worse at the high $\mathrm{pH}$ so that only the results obtained with $\mathrm{pH} 8.2$ were summarized in Table 1.

Accumulation and depletion effects of chloride ion should be negligible based on the magnitude of the chloride permeability (HoDGKIN and HorowICZ, 1959; HUTTER and NOBLE, 1960) and the time required for the potential measurements. 
Especially the crossing point in Fig. 1 at which the intracellular chloride concentration was determined corresponds to the $E_{\mathrm{Cl}}$, resulting in no net flux of chloride.

It is interesting to find that the upper and lower limit of the intracellular chloride concentration determined by radio-active tracer techniques (3.1-3.8 m mole/kg fiber water; ADRIAN, 1961) well involves the value determined with this method (Table 1). Our measurement further revealed that the $E_{\mathrm{C} 1}$ was significantly positive to the resting membrane potential (Table $1, P<0.01$ with $t$-test), strongly suggesting that there exists a chloride pump in the frog skeletal muscle. This was further supported by the experimental fact provided in Fig. 2. The difference between this result and the previous studies (Ling and GERARD, 1949; HoDGKIN and Horowicz, 1959; Hutter and Noble, 1960; Adrian, 1960, 1961) may be ascribed to a matter of the experimental resolution. In this connection, it is also interesting to have found that the chloride pump was not active without cooling when the frogs were in hibernation (unpublished observation).

The marked temperature dependency of the pumping activity around $5-10^{\circ} \mathrm{C}$ as seen in Fig. 2 suggests a molecular mechanism for the chloride pump ( $c f$. also HironaKa, 1974). It is worthy of note that some proteins denaturate when cooled below $10-15^{\circ} \mathrm{C}$ and some membrane lipids have their melting point in the range of the temperature concerned (LEHNINGER, 1970).

Active transport of chloride in neurons has been shown to be outwardly directed, and $E_{\mathrm{Cl}}$ serves as a hyperpolarizing battery for inhibitory postsynaptic potentials (LuX, 1971; RUSSELL and BROWN, 1972; LlinAS et al., 1974). In a number of other excitable cells, on the other hand, it has been proposed to occur inwardly, for instance in squid giant axon (KEYNES, 1963; Russell, 1976), smooth muscle (CASTEELS, 1971), and cardiac muscle (LAMB, 1961; LADLE and WALKER, 1975). Some one of the active transports seems related to regulate intracellular $\mathrm{pH}$ (RUSSELL and BORON, 1976). As the chloride conductance is relatively high in frog sartorius muscle (Hodgkin and Horowicz, 1959; HutTER and NoBLE, 1960), considerable work may be required to pump chloride against the potential difference. Further study is necessary to establish the molecular basis of the pumping mechanism and the biological significance of the inwardly-directed chloride pump in the frog skeletal muscle.

\section{REFERENCES}

Adrian, R. H. (1960) Potassium chloride movement and the membrane potential of frog muscle. J. Physiol. (Lond.), 151: 154-185.

AdRIAN, R. H. (1961) Internal chloride concentration and chloride efflux of frog muscle. $J$. Physiol. (Lond.), 156: 623-632.

Bolton, T. B. and Vaughan-Jones, R. D. (1977) Continuous direct measurement of intracellular chloride and pH in frog skeletal muscle. J. Physiol. (Lond.), 270: 801-833.

CAsteELs, R. (1971) The distribution of chloride ions in the smooth muscle cells of the guineapig's taenia coli. J. Physiol. (Lond.), 214: 225-243.

Cole, K. S. and Moore, J. W. (1960) Liquid junction and membrane potentials of the squid 
giant axon. J. Gen. Physiol., 43: 971-980.

Goldman, D. E. (1943) Potential, impedance, and rectification in membranes. J. Gen. Physiol., 27: 37-60.

HironaKa, T. (1974) Chloride-related depolarization of crayfish muscle membrane induced by L-glutamate. Nature, 248: 251-253.

HironaKa, T. and Morimoto, S. (1979) The resting membrane potential of frog sartorius muscle. J. Physiol. (Lond.), 297: 1-8.

Hodgkin, A. L. and Horowicz, P. (1959) The influence of potassium and chloride ions on the membrane potential of single muscle fibers. J. Physiol. (Lond.), 148: 127-160.

Hodgkin, A. L. and KATZ, B. (1949) The effect of sodium ions on the electrical activity of the giant axon of the squid. J. Physiol. (Lond.), 108: 37-77.

Hutter, O. F. and Noble, D. (1960) The chloride conductance of frog skeletal muscle. $J$. Physiol. (Lond.), 151: 89-102.

Hutter, O. F. and Warner, A. E. (1967) The pH sensitivity of the chloride conductance of frog skeletal muscle. J. Physiol. (Lond.), 189: 403-425.

Kernan, R. P., MacDermott, M., and Westphal, W. (1974) Measurement of chloride activity within frog sartorius muscle fibers by means of chloride-sensitive micro-electrodes. J. Physiol. (Lond.), 241 : 60P-61P.

Keynes, R. D. (1963) Chloride in the squid giant axon. J. Physiol. (Lond.), 169: 690-705.

LADLE, R. O. and WALKer, J. L. (1975) Intracellular chloride activity in frog heart. J. Physiol. (Lond.), 251 : 549-559.

LAMB, J. F. (1961) The chloride content of rat auricle. J. Physiol. (Lond.), 157: 415-425.

Lehninger, A. L. (1970) Biochemisty, Worth Publishers, Inc., New York.

Ling, G. and Gerard, R. W. (1949) The normal membrane potential of frog sartorius fibers. J. Cell. Comp. Physiol., 34: 383-396.

Llinas, R., BAKer, R., and Precht, W. (1974) Blockage of inhibition by ammonium acetate action on chloride pump in cat trochlear motoneurons. J. Neurophysiol., 37: 522-532.

Lux, H. D. (1971) Ammonium and chloride extrusion: hyperpolarizing synaptic inhibition in spinal motoneurons. Science, 173: 555-557.

Russell, J. M. (1976) ATP-dependent chloride influx into internally dialyzed squid giant axons. J. Membr. Biol., 28: 335-349.

Russell, J. M. and Brown, A. M. (1972) Active transport of chloride by the giant neuron of the Aplysia abdominal ganglion. J. Gen. Physiol., 60: 499-518.

Russell, J. M. and Boron, W. F. (1976) Role of chloride transport in regulation of intracellular pH. Nature, 264: 73-74.

WALKer, J. L. and Brown, H. M. (1977) Intracellular ionic activity measurements in nerve and muscle. Physiol. Rev., 57: 729-778. 